\title{
SOCIAL AND ECONOMIC SECURITY IN THE SYSTEM OF STATE PROTECTEDNESS
}

\author{
CShvaiba D., ORCID: 0000-0001-6783-9765, Ph.D., Belarusian Trade Union \\ of workers of chemical, mining and oil industries, Belarusian National Technical University, \\ Minsk,Belarus,shvabia@tut.by
}

\section{СОЦИАЛЬНО-ЭКОНОМИЧЕСКАЯ БЕЗОПАСНОСТЬ В СИСТЕМЕ ЗАЩИЩЕННОСТИ ГОСУДАРСТВА}

\begin{abstract}
СШвайба Д. Н., ORCID: 0000-0001-6783-9765, канд. экон. наук, Белорусский профсоюз работников химической, горной и нефтяной отраслей промышленности, Белорусский начиональный технический университет, 2. Минск, Беларусь, shvabia@tut.by
\end{abstract}

Abstract. Taking as a basis the scientific study of different concepts in the theory of security, it is necessary to assume that the inaccessibility of the threat in the absolute sense is impossible. In fact, there may not be a certain type of threat to a particular object in a specific period of time (if there is not yet or there is no longer a corresponding danger factor). It is necessary to take into account that interests are only a small part of a wide range of objects of state protection. This share differs subjectively and interacts with the implemented financial, economic and social policy, the productivity of which is largely dependent on the impact of individual groups of people and parties (based on socio-political preferences). In addition - it is quite a mobile category, which has the ability to change qualitatively. It is obvious that the danger is one of the many destructive moments of security, along with those of which have already been discussed, for example threat, challenge, risk, decline, crisis, cataclysm, destruction, deformation processes, etc. It is necessary to clarify that the danger in the context of the 'security triad' is always modified: in a short time, they have all chances to transform from the present into the probable and vice versa.

Аннотация. Взяв за базу научное исследование разных концепций в теории безопасности, необходимо предположить, что недоступность угрозы в абсолютном значении невозможна. В действительности может отсутствовать определенный вид угрозы для определенного объекта в конкретном промежутке времени (в случае если еще не существует или же уже не существует соответственного фактора опасности). Необходимо принимать во внимание то, что интересы - это лишь только малая доля широкого диапазона объектов государственной защищенности. Данная доля отличается субъективно и ведет взаимодействие с воплощаемой в жизнь финансово-экономической и общественной политикой, производность которой во многом находится в зависимости от воздействия отдельных групп людей и партий (на основе социально-политических предпочтений). Кроме этого - это довольно подвижная категория, которая имеет возможность качественно видоизменяться. Очевидно, что опасности - это один из многочисленных деструктивных моментов защищенности вместе с теми, о коих уже шла речь, к примеру: угроза, вызов, риск, упадок, кризисная обстановка, катаклизм, деструкция, деформационные процессы и др. Необходимо уточнить, что опасности в контексте «триады безопасности» всегда модифицируются: в период непродолжительного времени они имеют все шансы перевоплощаться из настоящих в вероятные и наоборот. 
Keywords: socio-economic protectedness, government, society, enterprise, employee, threat, protectedness, interests, economics, analysis, system.

Ключевые слова: социально-экономическая защищенность, государство, общество, предприятие, работник, угроза, защищенность, интересы, экономика, анализ, система.

The traditional understanding of security in the human community is based on such a category as an external or internal enemy. Following this thesis, security can be guaranteed only by defeating the enemy. As a result of such a victory, the results of the influence of the source of the threat on the public or another object, according to the researchers, are expressed:

- in the loss of the object of those own properties;

- in the loss of those own elements by the object;

- in the loss of links between segments of the object;

- in the loss of the facility's ability to develop;

- in weakening the functions of the object;

- in the complete destruction of the object, etc.

At the same time, in fact, the point orientation and the role of the subjective factor in the emergence of the threat experts denote such forms of danger:

- a call-an array of events, not every time threatening the essence, but requiring a response to them;

- a risk-the possibility of adverse and unnecessary results of the work of the subject [1, p. 87];

- threat - a more specific and specific type of danger created by the purposeful work of destructive forces, an array of criteria and moments that pose a threat to the basic needs of the individual, society, economic entity, country.

The degree of probability of occurrence and manifestations distinguish between threats: real and probable.

The factor of the existence of the already studied values of security was chosen the position of 'stability' (the ability of the object to save or restore the initial state of the subsequent impact of threats and dangers on it) (Table).

\section{THE CRITERIA FOR HAZARD CLASSIFICATION}

Table.

\begin{tabular}{ll}
\hline \multicolumn{1}{c}{ Classification criterion } & \multicolumn{1}{c}{ Dangers } \\
\hline Form of existence & Danger, risk, challenge, threat \\
The probability of & Abstract, concrete, real \\
Force of impact on the object & Acceptable, allowable, emergency \\
Scale, spatial characteristic & Global (universal), regional, country (local) \\
\hline
\end{tabular}

Note: development of the author.

The study of the threat implies the following nuances: identifying the source of the threat, danger, systematization of hazards, their prediction, identification, determination of the degree of threat, etc.

At the same time, in the literature it is possible to meet the systematization of the structure of relations that develop in the process of describing the dangers, while socio-economic relations in the presented section are considered rather narrowly and unilaterally, assuming only professional training, training, maintenance of physiological and psychological state, the standard of living of the population [2, p. 51]. 
Taking as a basis for the study of advanced approaches, we proposed the following definition, methodologically providing further study of socio-economic security in the system of state protection: security-inaccessibility, prevention, destruction, minimizing the threat (risk, danger, challenge), protection of the object from the influence of internal and external forces (factors) capable of causing harm to it or eliminate.

This definition allows you to mark the following security types:

- hypothetical security-the absolute absence of threats, including the ability of some unsafe environments, phenomena for society;

- real security-the ultimate security against threats, the ability to fully confront them.

Taking as a basis the scientific study of different concepts in the theory of security, it is necessary to assume that the inaccessibility of the threat in the absolute sense is impossible. In fact, there may not be a certain type of threat to a particular object in a specific period of time (if there is no already or there is no corresponding hazard factor).

It is necessary to take into account that interests are only a small part of a wide range of objects of state protection. This share differs subjectively and interacts with the implemented financial, economic and social policy, the productivity of which is largely dependent on the impact of individual groups of people and parties (based on socio-political preferences). In addition - it is a quite mobile category, which has the ability to change qualitatively.

It is obvious that the danger is one of the many destructive moments of security, along with those of which have already been discussed, for example: threat, challenge, risk, decline, crisis, cataclysm, destruction, deformation processes, etc.it Is necessary to clarify that the danger in the context of the 'security triad' is always modified: in a short period of time they have all chances to transform from the present into the probable and Vice versa.

In the context of defense - in fact, the local share of measures that ensure the measured and normal development of the economy. In this case, with a certain assumption, it is possible to recognize that all kinds of mechanisms and tools aimed at ensuring the sustainable development of the economy have every chance to be used as measures for the defense of socio-economic security.

The scope of main interests, selected in consultation with spheres of social structures, show the need to study more 1st methodologically important nuances in the analysis of safety. We are talking about the types of security, its components and nuances [3, p. 12]. In most cases, security experts consider it appropriate to introduce the term 'types of security' when considering the issue presented.

The types of security include financial, economic, political, military security, etc. This division is based on the variety of spheres of society and the individual. So, types of safety contain properties of a condition or directly the public object, or criteria of its activity. Taking into account this precedent, we consider it appropriate to single out social and economic security as a separate type of security.

The difficulty in ensuring social and economic security in our country was actualized in connection with the transition from the administrative system of management to the market [4-5]. At the stage of transition from XX to XXI art. when modifying the political, financial and economic systems, the exposure of the Belarusian economy not only to internal changes and their results, but also to the influence of other countries and the global economy as a whole, state, and in particular socio-economic, security acquired a special meaning.

The policy of ensuring the social and economic security of the Republic of Belarus is currently based on the officially adopted normative documents, the basic of which is the Constitution of the Republic of Belarus and the Concept of national security of the Republic of Belarus [6]. 
In this case, socio-economic security is considered as a system that includes external and internal factors, the main interests of the objects of the protection — the individual, society, economic entity, country, actual and probable dangers, and subjects of security.

In addition, it is impossible not to take into account that the quality and effectiveness of practical work to ensure the socio-economic security of the state are largely dependent on the content and research of the security issue, in agreement with which it is implemented — on the theory.

We are not faced with the task of conducting an in-depth analysis of conceptual and categorical approaches related to socio-economic security, since the presented problem is studied quite extensively in a number of well-known works $[1$, p. $31 ; 7$, p. 207; 8, p. 53; 9, p. 107; 10, p. 657,11 , p. $79 ; 12$, p. $40 ; 13$, p. $6 ; 14$, p. $28 ; 15$, p. $49 ; 16$, p. $24 ; 17$, p. 88].

More common at the moment is considered to be an objective approach to the definition of the essence of socio-economic security, according to which: socio-economic security — the position of protection of the basic needs and interests of public facilities in the financial, economic and moral spheres from internal and external challenges, dangers and threats [18, p. 62].

This approach shows that the economic and social security of the person is under threat if the individual is deprived of access to productive resources (land, capital, labor, technology); in the case of which is the property of the individual property, rights and guarantees he has selected; if the individual has no opportunity to fully exercise the corresponding rights in the event of disability.

The object of socio-economic security is not only the person but also the country, the government, society as a whole, its different spheres, the economy as a whole, its different segments and components, the public sphere, economic entities.

According to V. K. Senchagov, socio-economic security is the position of the economy and government structures, which guarantees the protection of state interests, social development of the state as a whole, the necessary defense potential, including in the most adverse situations in the internal and external environments.

The protection of the interests of the state is guided and guaranteed directly by the possibility of power structures to form mechanisms for the implementation and defense of the interests of people, maintaining the socio-political strength of society.

Taking as a basis the study of advanced approaches to the definition of socio-economic security, it should be noted that the evolution of the current period in the theory of socio-economic security is reflected in the postulation of the following conceptual provisions:

- interpretation of security in the field of socio - economic security of the country, and not as a point sector of the complexity of the defense of state interests;

- the traditional division of security threats into internal and external with priority (in real conditions) of internal dangers (here it is necessary to understand that borders between them are erased);

- non-market Genesis of socio-economic security, as the emergence of these problems is caused not only by objectively relevant negative manifestations of market regulation, but also the dangers of a subjective and functional way of life due to regulatory failures;

- the need to determine the security thresholds to obtain an effective tool to identify the most vulnerable factors of the economy and the use of statistical data in the adoption of state decisions in the field of regulation of the reproductive process;

- taking into account the state interests of security in the public sphere in the formation of the forecast and the program of economic development of the state.

It seems indisputable that socio-economic security - an element of the basis of state protection, its mandatory part in line with the financial, economic, political, social, military, etc., it 
has taken the position of an important part of the entire system of state protection. It is concluded that socio-economic security is the key to sustainable, measured and measured development of the state, its independence.

So, the purpose of the state strategy is to provide such a level of economic development, which would form viable circumstances for the existence and full-fledged formation of the individual, socio-economic strength of society and maintain the unity of the country, able to safely resist the influence of internal and external hazards. Based on the above, financial and economic circumstances affect not only the state of the individual or the territory but also the entire state affects all areas of work, which, at first glance, in no way related to this opinion.

It should be noted that socio-economic security implies a state of the economy in which the defense of the financial and economic interests of the individual, society, economic entity, country, public policy direction and competitiveness is guaranteed.

At the same time, the definition of the term 'socio-economic security' in the integrated system of state protection should include the following provisions:

1. Socio-economic security is not considered an end in itself, it is only one of the main mandatory indicators of state protection of any country and is tightly intertwined with other types of security: financial, economic, political, public, military, information, etc.

2. It is impossible to guarantee unconditional socio-economic security, but it is possible to guarantee a certain degree of safety from adverse external and internal hazards.

3. The object of defense can be considered vital socio-economic interests-meaningful needs of the individual, country, society, economic entity in public security. At the same time, organizations cannot be considered as carriers of these interests as material objects. If we are talking about collectives, then it is necessary to perceive public groups, that is, the components of society (civil society or the country, if we are talking about state organizations).

4. The location of objects of social and economic security in accordance with the principles of formal logic has the ability to be: a person, a country, a government, a society, an economic entity. A person does not have the opportunity to be an absolute subject of ensuring socio-economic security, due to the fact that this is only the public side of the bio-social being-a person, and in the essence of his behavior are just real needs: food, housing, etc.

5. It is impossible to ignore the focus on increasing the number and solidity of challenges, dangers and threats in the financial and economic sphere, which is due to various reasons, but just with the contradiction between the limited physical resources on Earth and the rise in demand for them.

6. It should be understood that the challenges, dangers and threats in the financial and economic sphere have all chances to have internal and external sources, characterizing the internal and external characteristics of socio-economic security.

Based on the above, it seems likely and appropriate to form a more generalized definition of socio-economic security of the person, country, society, economic entity as part of the system of state protection.

Socio-economic security is a mandatory element of the system of state protection, inextricably linked with the financial, economic, political, social and military units, characterized by the state of security of the main interests of the person, country, society and economic entity in the financial, economic and public spheres from internal and external challenges, dangers and threats.

This definition does not allow to fully disclosing the issue. It is in constant dynamics and has the ability to be adjusted; it has all the chances to make additions and changes. At the same time, it reflects the whole essence of the problems, which makes it possible to move to a more serious study of the role of socio-economic security of the Republic of Belarus in the system of state protection. 
This fact makes it possible to form a definition of the concept of socio-economic security in the Concept of national security of the Republic of Belarus.

Due to the fact that the theoretical and methodological basis for the analysis of security problems was the objectivist approach to the study of socio-economic security, in accordance with it, socio-economic security has the ability to be considered as the security of the main interests of public facilities in the financial and economic sphere from internal and external challenges, dangers and threats.

In the context of the presented approach, socio-economic security is studied as a situation in which sustained financial and economic recovery, the satisfaction of social needs at a sufficient level, effective management.

\section{References:}

1. Golovnya, E. (2013). The Causes of Social Risks and Their Implications [Prichiny sotsial'nykh riskov i ikh posledstviya]. Problemy teorii i praktiki upravleniya, (2), 87-92.

2. Knyazev, S. N. (2012). Osnovy natsional'noi i ekonomicheskoi bezopasnosti. Minsk, Belorus. nats. tekhn. un-t. 144.

3. Labush, N. S. (1999). Gosudarstvo, silovoi mekhanizm, vooruzhennye sily. SPb, 179.

4. Shvaiba, D. (2019). Dynamic regression models of forecasting indicators of social and economic security. Bulletin of Science and Practice, 5(1), 249-257.

5. Shvaiba, D. (2018). Socio-economic security of the hierarchical system. Bulletin of Science and Practice, 4(6), 248-254.

6. Ob utverzhdenii Kontseptsii natsional'noi bezopasnosti Respubliki Belarus': Ukaz Prezidenta Resp. Belarus', 9 noyab. 2010 g., № 575: v red. Ukaza Prezidenta Resp. Belarus' ot 24.01.2014 g. Minsk. 2017.

7. Kaimanakov, S. V. (2015). Sotsial'no-ekonomicheskaya bezopasnost' Rossii: soderzhanie, otsenka i obespechenie. Filosofiya khozyaistva, (6). 203-212.

8. Magomedov, M. G., Samygin, S. I., \& Shcherbakova, L. I. (2017). The concept of market self-regulation in the context of socio-economic security [Kontseptsiya rynochnoi samoregulyatsii $\mathrm{v}$ kontekste sotsial'no-ekonomicheskoi bezopasnosti]. Gumanitarnye sotsial'no-ekonomicheskie $i$ obshchestvennye nauki, (1). 52-55.

9. Pryadko, I. P. (2016). Sotsial'no-ekonomicheskie aspekty geopoliticheskoi bezopasnosti: ot gipotez k nauchnoi teorii. In: Materialy ezhegodnoi nauchno-prakticheskoi konferentsii pamyati Daga Khammarshel'da, 2. 107-110.

10. Chichkanov, V. P., \& Belyaevskaya-Plotnik, L. A. (2016). Analysis of the approaches to the assessment of regional processes of formation of social and economic security [Analiz podkhodov $\mathrm{k}$ otsenke regional'nykh protsessov formirovaniya sotsial'no-ekonomicheskoi bezopasnosti]. Ekonomika regiona, 12(3). 654-669. doi:10.17059/2016-3-4 УДК 332.143

11. Akjulov, R. I. (2015). Problems and prospects of monitoring and assessment of socioeconomic security of the Russian regions [Problemy i perspektivy monitoringa i otsenki sotsial'noekonomichesko bezopasnosti rossiiskikh regionov]. Voprosy upravleniya, (1). 78-86.

12. Malyshkin, A. P. (2015). Sovremennye problemy obespecheniya sotsial'noekonomicheskoi bezopasnosti regiona. Sotsial'no-ekonomicheskie yavleniya i protsessy, 10(12), 3943.

13. Abalkin, L. I. (2006). Razmyshleniya o dolgosrochnoi strategii, nauke i demokratii. Voprosy ekonomiki, (12), 4-19.

14. Bogdanov, I. Ya. (2001). Ekonomicheskaya bezopasnost' Rossii: teoriya i praktika. Moscow, 351. 
15. Illarionov, A. I. (1998). Kriterii ekonomicheskoi bezopasnosti. Voprosy ekonomiki, (10), $35-58$.

16. Yasin, E., \& Yakovlev, A. (2004). Konkurentosposobnost' i modernizatsiya Rossiiskoi ekonomiki. Voprosy ekonomiki, (7). 4-34.

17. Petrenko, I. (2003). O prichinakh aktualizatsii issledovaniya ekonomicheskoi bezopasnosti Rossii. Rossiiskii ekonomicheskii zhurnal, (3), 87-89.

18. Mukhin, K. V. (2004). Ekonomicheskaya bezopasnost' v sisteme natsional'noi bezopasnosti Rossiiskoi Federatsii. Moscow, 62.

\section{Список литературы:}

1. Головня Е. Причины социальных рисков и их последствия // Проблемы теории и практики управления. 2013. №2. С. 87-92.

2. Князев С. Н. Основы национальной и экономической безопасности. Минск: Белорус. нац. техн. ун-т, 2012. 144 с.

3. Лабуш Н. С. Государство, силовой механизм, вооруженные силы. СПб., 1999. 179 с.

4. Shvaiba D. Dynamic regression models of forecasting indicators of social and economic security // Бюллетень науки и практики. 2019. Т. 5. №1. С. 249-257.

5. Shvaiba D. Socio-economic security of the hierarchical system // Бюллетень науки и практики. 2018. Т. 4. №6. С. 248-254.

6. Об утверждении Концепции национальной безопасности Республики Беларусь: Указ Президента Респ. Беларусь, 9 нояб. 2010 г., № 575: в ред. Указа Президента Респ. Беларусь от 24.01.2014 г. Минск, 2017.

7. Кайманаков С. В. Социально-экономическая безопасность России: содержание, оценка и обеспечение // Философия хозяйства. 2015. №6. С. 203-212.

8. Магомедов М. Г., Самыгин С. И., Щербакова Л. И. Концепция рыночной саморегуляции в контексте социально-экономической безопасности // Гуманитарные социально-экономические и общественные науки. 2017. №1. С. 52-55.

9. Прядко И. П. Социально-экономические аспекты геополитической безопасности: от гипотез к научной теории // Материалы ежегодной научно-практической конференции памяти Дага Хаммаршельда. М., 2016. Т. 2. С. 107-110.

10. Чичканов В. П., Беляевская-Плотник Л. А. Анализ подходов к оценке региональных процессов формирования социально-экономической безопасности // Экономика региона. 2016. Т. 12. №3. С. 654-669. DOI: 10.17059/2016-3-4 УДК 332.143.

11. Акьюлов Р. И. Проблемы и перспективы мониторинга и оценки социальноэкономической безопасности российских регионов // Вопросы управления. 2015. №1. С. 7886.

12. Малышкин А. П. Современные проблемы обеспечения социально-экономической безопасности региона // Социально-экономические явления и процессы. 2015. Т. 10. №12. C. 39-43.

13. Абалкин Л. И. Размышления о долгосрочной стратегии, науке и демократии // Вопросы экономики. 2006. №12. С. 4-19.

14. Богданов И. Я. Экономическая безопасность России: теория и практика. М. 2001. $351 \mathrm{c}$.

15. Илларионов А. И. Критерии экономической безопасности // Вопросы экономики. 1998. №10. С. 35-58.

16. Ясин Е., Яковлев А. Конкурентоспособность и модернизация Российской экономики // Вопросы экономики. 2004. №7. С. 4-34. 
17. Петренко И. О причинах актуализации исследования экономической безопасности России // Российский экономический журнал. 2003. №3. С. 87-89.

18. Мухин К. В. Экономическая безопасность в системе национальной безопасности Российской Федерации. М., 2004. С. 62.

Работа поступила

в редакциюю 17.03.2019 2.
Принята к публикациии

21.03.2019 2.

Ссылка для ичитирования:

Shvaiba D. Social and Economic Security in the System of State Security // Бюллетень науки и практики. 2019. Т. 5. №4. С. 280-287. https://doi.org/10.33619/2414-2948/41/38.

Cite as (APA):

Shvaiba, D. (2019). Social and Economic Security in the System of State Security. Bulletin of Science and Practice, 5(4), 280-287. https://doi.org/10.33619/2414-2948/41/38. 